\section{Modeliranje poslovno - ekonomskih strategija kao platforme investicijske politike u uvjetima rizika}

\section{Modelling of business-economic strategies as a platform of investment policy in the risk exposure}

\section{Sažetak}

Investicijska politika i ulaganje predstavljaju bitne zadatke, ali istovremeno i probleme gotovo svih društveno ekonomskih sustava. Ulaganje predstavlja platformu razvoja i nužnost opstanka tržišno - ekonomskih sustava, a podrazumijeva poduzimanje odgovarajućih mjera i aktivnosti kako bi se uloženi kapital, putem odabrane djelatnosti, trajno uvećavao. Ekonomski pokazatelji, posebno u razdoblju ekonomske krize, oslikavaju nepovoljne i općeprisutne tendencije neželjenog poslovnog rezultata, proizlaze iz neodgovarajuće politike poslovanja, pri čemu investiranje i investicijsku politiku možemo označiti liderima u području poslovnih neuspjeha. Nemogućnost preciznog predviđanja poslovnih ishoda vezanih za investicijska ulaganja, vremenska disproporcija između ulaganja i njihovih početnih, a posebno optimalnih posljedica, kao i ireverzibilnost uloženih sredstava, dodatno otežavaju formulaciju odgovarajuće strategijske platforme investicijske politike. Modeliranje poslovnih strategija u uvjetima turbulentnih društveno - ekonomskih, tehnoloških, kao i tržišnih čimbenika predstavlja inspiraciju i izazov istraživaču da izborom odgovarajućeg teorijskog modela reprezentativno približi realnost. Vjerno preslikavanje realnosti podrazumijeva suptilan pristup klasifikaciji navedenih čimbenika prema važnosti, razini utjecaja, kao i odgovarajuću kvantifikaciju, prepoznavanje i uobličavanje oblika i mjere njihove međuzavisnosti. Model matematičke simulacije predstavlja teorijski model koji omogućava predviđanje poslovnih ishoda u uvjetima rizika uz njihovo iskazivanje korespondentno sa slučajnom komponentom koja na njih utječe. Ključno pitanje navedenog pristupa odnosi se na odgovarajući izbor distribucije vjerojatnosti slučajne varijable, prilagođene uvjetima ulaganja, pri čemu je potrebno uvažiti i empirijsku komponentu teritorijalno - zemljopisnog prostora na kojem se investicija realizira, a pri tome imati uvid i u druge aspekte izbora distribucije, kao što su iskustva u području odabranog područja ulaganja (granske specifičnosti) i prilagođenost određenom teorijskom modelu. Simuliranje efekata investicijskih ulaganja osigurava objektivan pristup strategijskom izboru i prikladan proračun monetarnih posljedica prije operacionalizacije projekta.

Ključne riječi: investicijska politika, poslovno okruženje, ireverzibilnost uloženih sredstava, proračun poslovnih ishoda, učinkovitost ulaganja

JEL klasifikacija: C1

\section{Abstract}

Investment policy and investing represent essential tasks, and also major issues of almost all socio-economic systems. Investment represents a development platform and is necessary for survival of market and economic systems; it comprises undertaking appropriate measures and activities to have the invested capital continuously increasing through exercising selected operations. Economic indicators, especially in the period of economic crisis, reflect unfavourable and widespread tendencies of unwanted business result that arise from inadequate business policy, where investing and investment policy may be marked
Izv. prof.dr.sc. Mirjana Landika

Panevropski Univerzitet Apeiron, Banja Luka E-mail: mirjana.landika@gmail.com

Izv. prof.dr.sc.Sanel Jakupović

Panevropski Univerzitet Apeiron, Banja Luka

E-mail: sanel.e.jakupovic@apeiron-edu.eu

\section{Mr.sc. Vedran Šupuković}

CIAK d.0.0.

E-mail:vedran.supukovic@ciak.hr

Assoc. prof. Mirjana Landika, PhD

Paneuropean University Apeiron, Banja Luka

E-mail:mirjana.landika@gmail.com

Assoc. prof. Sanel Jakupović, PhD

Paneuropean University Apeiron, Banja Luka E-mail: sanel.e.jakupovic@apeiron-edu.eu

\section{Vedran Šupuković, MSc}

CIAK Ltd.

E-mail:vedran.supukovic@ciak.hr 
Landika, M., Jakupović, S., Šupuković, V.

Modeliranje poslovno ekonomskih strategija kao platforme investicijske politike u uvjetima rizika

as leaders in the area of business failure. Impossibility to accurately assume business results related to the investment, time disproportion between the investment and its initial, and particularly, optimal effects, and also irreversibility of the investment, further complicate the formulation of adequate investment policy strategy platform. Modelling of business strategies in the exposure to turbulent socio-economic, technological and market factors is an inspiration and a challenge to the researcher to representatively mirror the reality by selecting adequate theoretical model. Faithful mirroring of the reality involves a subtle approach to classification of these factors by importance, level of influence, and also adequate quantifying, identifying and shaping the form, as well as the extent of their interdependence. Mathematical simulation model is a theoretical model that allows prediction of business results in the risk exposure expressed correspondently with the random component that is influencing it. The major concern of the mentioned approach is an adequate selection of the probability distribution of a random variable, customized to the investment conditions. It is necessary here to take into account empiric component of territorial-geographic area of the investment implementation, whereby it is necessary to have insight into other aspects of distribution selection, such as experiences in the selected investment area (sectoral specificity) and adjustment to particular theoretical model. Simulation of investment effects provides objective approach to strategic choice and adequate calculation of monetary results before operationalization of the project.

Keywords: investment policy, business environment, irreversibility of investment, calculation of operating expense, investment effectiveness

JEL classification: C1

\section{Uvod}

Poslovne jedinice društveno - ekonomskih sustava imaju zadatak i potrebu da, prilagođavanjem vlastitih potencijala promjenjivim uvjetima privređivanja, doprinose ekonomskom i globalnom društvenom napretku. Navedeni postupci realiziraju se postupkom ulaganja, pri čemu se raspoloživi financijski potencijali angažiraju radi neostvarenih beneficija, čija realizacija predstavlja neizvjesno poslovno očekivanje.

Tvrtka vrši razmjenu izvjesnog materijalnog dobra za niz financijsko - poslovnih očekivanja u odnosu na određene očekivane buduće korisničke potrebe. Potencijalne beneficije investiranja odnose se na određeni poslovni rezultat koji se ne mora realizirati u željenom obliku. Smisao ulaganja sadržan je u ostvarivanju odgovarajućih učinaka, koji se mogu kretati od krajnje neželjenih, preko željenih, do neočekivano povoljnih, pri čemu u trenutku realizacije nije moguće pouzdano pretpostaviti njihove dimenzije.

Učinci investiranja imaju više dimenzija, a odnose se na učinke koji se žele ostvariti (troškovi poslovanja, poslovni prihodi, položaj zaposlenih, poslovni rizik), konkurentsku poziciju (ofenzivne - potiču konkurente na reakciju ili defenzivne - odgovor na konkurentsku akciju), oblik ulaganja (oprema, razvoj proizvoda, način poslovanja, tržišno pozicioniranje), odnos prema tehnološkim promjenama ili vrstu strategijskog utjecaja (Dean, 1951.).

Procjena učinaka investiranja zahtijeva odgovarajuću analizu rizika kroz postupak ocjene raspona vrijednosti svakog značajnog čimbenika kao i distribuciju njihove vjerojatnosti, zatim kombinacijom čimbenika izračunavati stopu profitabilnosti veći broj puta u svrhu formiranja potpunije informacijske platforme donosiocu odluka (Hertz, 1990.).

Model matematičke simulacije, uz odgovarajuću primjenu, omogućuje da se nadogradi konvencionalni pristup kalkulacije u odnosu na poslovno očekivanje, što omogućuje da se poslovni ishod poveže s vjerojatnošću slučajne varijable koja utječe na njega i to kroz odabrani vremenski period. Navedeni pristup omogućuje i da se modelom obuhvati projektirano razdoblje eksploatacije investicije. Modelirane informacije određene su klasifikacijom varijabli, uočavanjem i prepoznavanjem njihovih veza i odnosa, kao i odgovarajućim izborom distribucije vjerojatnosti slučajne varijable i perioda njezine eksploatacije. 


\section{Investicijska ulaganja kao platforma razvojne politike poslovnih sustava}

Investicija se može objasniti kao ulaganje u sadašnjost, primarno novčanih sredstava, radi stjecanja, određenih ekonomskih dobiti, odnosno profita, $u$ budućnosti. Pri tome se može ulagati u financijske oblike imovine i s njima izjednačena ulaganja ili u realne oblike imovine koji omogućavaju ostvarivanje dobiti kroz određene produktivne poslovne aktivnosti.

Oblici investicija, odnosno ulaganja, se mogu promatrati s nekoliko različitih stajališta. Tako se razlikuju poslovna ulaganja, promatrana s razine procesa budžetiranja kapitala investicijskih projekata, odabirom različitih kriterija 0 izboru investicijskih projekata, dok se s ekonomskog aspekta promatra kao vrijeme u kojem se resursi ne koriste za potrošnju već se koriste za buduću proizvodnju. S financijskog stajališta investicije promatramo kao ulaganje u različite vrijednosne papire, sa strane osobnih financija, investiciju možemo promatrati kao izlaganje riziku, osobnu štednju u očekivanju dobiti. Kada je riječ o nekretninama, to su ulaganja $\mathrm{u}$ rezidencijalne ili poslovne nekretnine $\mathrm{s}$ ciljem stjecanja tekućih dohodaka ili kapitalnih dobitaka uslijed aprecijacije vrijednosti investicije. Investiranje i odluke 0 investicijama temelje se na konceptu budžetiranja kapitala.

Investicije mogu davati pozitivne ili negativne stope prinosa na investirana sredstva. Pozitivan prinos ostvaruju investicije koje imaju čistu sadašnju vrijednost jednaku ili veću od nule, dok negativne stope prinosa odbacuju investicije koje imaju negativnu čistu sadašnju vrijednost.

Razmatranje pozitivnih prinosa dijeli se na dva koncepta:

- pozitivni realni prinosi

- pozitivni apsolutni prinosi.

Pozitivni realni prinosi označavaju prinos na neku vrstu imovine koji nadmašuje prinose na usporedive vrste imovine.

Apsolutni pozitivni prinos za benchmark uzimaju prinos na kratkoročne državne dužničke vrijednosne papire i trezorske zapise. Tako da apsolutni pozitivni prinosi označavaju prinos koji nadmašu- je prinos na trezorske zapise neovisno o smjeru i intenzitetu cjenovnih promjena imovine koja se nalazi u investicijskom portfelju.

U procesu budžetiranja kapitala, financijski rukovoditelj pronalazi investicijske prilike koje imaju veću vrijednost za tvrtku nego što je trošak njihovog stjecanja. Drugim riječima, predmet proučavanja, u procesu budžetiranja kapitala, su čisti novčani tokovi koje generira upotreba neke imovine u odnosu na trošak stjecanja te iste imovine.

Koncept budžetiranja kapitala temelji se, pored procjene očekivanih novčanih tokova u budućnosti, na procjeni rizika prilagođene diskontne stope, to jest zahtijevanog prinosa.

Ovdje se uvodi koncept čiste sadašnje vrijednosti, to jest diferencijala sadašnje vrijednosti očekivanih novčanih tokova i investicijskog troška neke imovine ili projekta.

Imovina ili projekt koji imaju pozitivnu čistu sadašnju vrijednost povećavaju bogatstvo običnih dioničara, odnosno vlasnika, te su prihvatljivi sa stajališta rizika i nagrade. Tako se procjena dinamike i rizika ostvarivanja novčanih tokova nalazi u središtu budžetiranja kapitala i odluka o investiranju.

Temeljna tri koncepta odlučivanja u procesu investicijskog odlučivanja su:

- budžetiranje kapitala u smislu procjene veličine i dinamike očekivanih novčanih tokova te rizika prilagođene diskontne stope

- struktura kapitala - različite kombinacije dugoročnog duga vlastitog kapitala tvrtke, koja omogućavaju dugoročne investicije.

- upravljanje neto obrtnim kapitalom - upravljanje kratkoročnom imovinom (zalihe, novčana sredstva) i kratkoročnim obavezama poduzeća s ciljem neometanog obavljanja svakodnevnih poslovnih aktivnosti.

Princip pri budžetiranju kapitala sadržan je u vremenskoj vrijednosti novca. Vremenska vrijednost novca određena je tehnikom ukamaćivanja, odnosno diskontiranja. Tehnikom diskontiranja određuje se sadašnja vrijednost očekivanih novčanih tokova, dok se tehnikom ukamaćivanja određuje buduća vrijednost novčanih tokova. Proces odluka u sklopu budžetiranja kapitala sadržan je u kriterijima inves-
Landika, M., Jakupović, S., Šupuković, V.

Modeliranje poslovno ekonomskih strategija kao platforme investicijske politike u uvjetima rizika 
Landika, M., Jakupović, S., Šupuković, V.

Modeliranje poslovno ekonomskih strategija kao platforme investicijske politike $u$ uvjetima rizika ticijskog odlučivanja od kojih su najznačajniji koncept čiste sadašnje vrijednosti te koncept interne stope profitabilnosti očekivanih čistih novčanih tokova.

U procesu odlučivanja o oblicima ulaganja, dominantan je pristup moderne teorije portfelja Harry Markowitza i model procjene kapitalne imovine koji ukazuje na način kako se kombiniranjem dionica u portfelju može postići najniži rizik za neki očekivani prinos, ili najviši mogući prinos za zadanu razinu rizika. Rizik se ovdje promatra tehnički, kao odstupanje očekivane cijene promatrane imovine u portfelju od ostvarene cijene na uređenom javnom tržištu. Odluke o ulaganju i oblicima ulaganja obuhvaćaju čitav niz povezanih rizika od kojih su najvažniji: tržišni rizik, politički rizik, rizik likvidnosti, valutni rizik, kreditni rizik, rizik promjene kamatnih stopa, rizik promjene poreznih propisa te specifični rizici vezani uz pojedini oblik investicije.

\section{Utjecaj okruženja na investiranje u Republiku Srpsku}

Situacija na globalnom političko - ekonomskom planu značajno utječe na investiranje u Republici Srpskoj (RS). Što se tiče stranih ulaganja, politička nestabilnost i neučinkovita administracija su prepreke za takvu vrstu ulaganja.

Vrlo kompleksna organizacija i način funkcioniranja države, nedefinirani zakoni koji se često mijenjaju, znatno utječu na investiranje u RS. Najveći problemi s kojima se susreću strani ulagači su nedostatak kvalificirane radne snage, problem sa slabim napajanjem električne energije, problem nerješivih imovinsko pravnih odnosa, administrativne prepreke, program dobivanja poticaja, kao i porezna politika.

Negativna demografska kretanja kao i padajuća kupovna moć dodatno utječu na ulaganja. Vrlo je važno da se takve okolnosti što prije poboljšaju kako bi privukli prijeko potreban kapital, nove investicije, nove tehnologije i zapošljavanja.

Pored svih navedenih poteškoća, kada se govori o stranim ulagačima, svjedočanstva istih potvrđuju da je RS nepoželjna destinacija za značajnija investiranja.

Društveno-ekonomska ocjena ulaganja podrazumijeva ocjenu profitabilnosti ili ekonomske ocjene s gledišta države. Ocjena se izražava učinkom ulaganja na stvaranje društvene akumulacije, odnosno, mjera vrijednosti je doprinos projekta na povećanje bruto-društvenog proizvoda.Ako su koristi ulaganja veće od troškova tada dolazi do povećanja bruto-društvenog proizvoda i ulaganja su prihvatljiva za državu.

Kod takve ocjene potrebno je formirati društveno-ekonomski tijek ulaganja koji predstavlja pregled identificiranih koristi i troškova projekta.

Osnovni kriteriji ocjene društvene profitabilnosti ulaganja su isti kao i kod tržišno-financijske ocjene, s tim da postoje i osnovni kriteriji za ocjenu efikasnosti ulaganja: povećanje zaposlenosti, učinci na platnu bilancu, povećana iskorištenost slobodnih kapaciteta, utjecaj na tehničko-tehnološku razinu države, utjecaj na regionalni razvoj i utjecaj na radnu i životnu sredinu.

\section{Simulacijski pristup modeliranju optimalnih poslovnih strategija}

Osim kvalitativnog, kvantitativi investicijski model, u dinamičnim uvjetima tržišne realizacije, zahtijeva korespondenciju čimbenika različitih pojavnih oblika, strukture te intenziteta međuovisnosti u kontekstu opredjeljenja optimalne razine poslovne učinkovitosti.Suvremeni uvjeti privređivanja su inspiracija i izazov poslovnim sustavima da sustavom organiziranih i svrsishodnih aktivnosti realiziraju promjene kojima će unaprijediti vlastitu konkurentsku poziciju. Optimalna investicijska politika predstavlja balansiranje resursnim mogućnostima u funkciji inoviranja tržišne ponude, a radi učrršćivanja konkurentske pozicije.

Upravljanje poslovnim ishodima zahtijeva suptilnu kompoziciju modela odlučivanja koji ima moć matematičkim relacijama oslikati i vjerno predstaviti razinu realnosti na koju se odnosi, te omoguciti primjeren izračun poslovne učinkovitosti čime postaje potentat u smislu predviđanja budućih poslovnih rezultata u uvjetima rizika. Modeli simulacije omogućuju povezivanje poslovnih rezultata s ulaznim i slučajnim varijablama uz prolazak razine realnosti unaprijed pretpostavljenom vremenskom rutom.

Model simulacije se namjenski prilagođava problemu odlučivanja, što zahtijeva detekciju distribucije vjerojatnosti konkretnih sistemskih kategorija u kontekstu njihovog slučajnog izbora, a omogućuje prilagođa- 
Tablica 1. Pokazatelji poslovne aktivnosti tvrtke M.tel a.d. Banja Luka za razdoblje 2009. - 2015.

\begin{tabular}{|c|c|c|}
\hline Godina & $\begin{array}{c}\text { Ostvarena razina investicijskih } \\
\text { ulaganja (miljuni BAM) }\end{array}$ & $\begin{array}{c}\text { Ostvarena neto } \\
\text { dobit (tisuće BAM) }\end{array}$ \\
\hline 2009 & 2,91 & 102,63 \\
\hline 2010 & 19,88 & 108,11 \\
\hline 2011 & 30,17 & 107,43 \\
\hline 2012 & 13,87 & 110,55 \\
\hline 2013 & 34,18 & 101,02 \\
\hline 2014 & 26,27 & 106,38 \\
\hline 2015 & $-50,21$ & 76,33 \\
\hline
\end{tabular}

Izvor: Deloitte (2015.).

vanje konvencionalnim pravilima odlučivanja.

Monte Carlo metoda simulacije podrazumijeva provođenje eksperimenta kojim se vrši predviđanje ishoda odabranih alternativa u izabranom vremenskom intervalu s ciljem njihove usporedbe. Sagledavanje implikacija odabranih alternativa prije ili tijekom izvršenja omogućuje usklađivanje poslovnog sustava postavljenim ciljevima slučajnim izborom odgovarajućih sustavnih kategorija.

Modeliranje vjerojatnosti kriterijske varijable (y) podrazumijeva preciznu logičku proceduru, koja obuhvaća sljedeće korake:

- Identifikacija kriterijske i relevantnih nezavisnih varijabli

- Kvantifikacija varijabli

- Međusobni odnosi varijabli

- Ocjena raspodjele vjerojatnosti za ulazne varijable

- Ocjena raspodjele vjerojatnosti zavisne varijable (y) na bazi raspodjele nezavisnih varijabli $\left(\mathrm{x}_{1}, \mathrm{x}_{2}\right.$ ..., $\mathrm{x}_{\mathrm{n}}$ )

- Korištenje tehnike Monte Carlo simulacije za dobivanje zadovoljavajuće raspodjele vjerojatnosti izlazne varijable

- Evaluacija projekta koristeći dio ili sve informacije sadržane u ocjenjenoj raspodjeli (Mikić, 2006.).

\section{Principi formulacije i stohastička korekcija investicijskih strategija razina realnosti}

Konstrukcija odgovarajućeg modela matematičke simulaciie omoaućava razumijevanje kompleksnih poslovnih problema, proračun profitabilnosti, a time učinkovitost poslovanja postaje visoko pouzdano poslovno očekivanje. Poslovanje tvrtke iz područja telekomunikacijske djelatnosti pratimo uvidom u objavljena poslovna izvješća za razdoblje 2009. - 2015. godine, pri čemu koristimo podatke 0 vrijednosti investicijskih ulaganja i ostvarenoj neto dobiti u promatranom vremenskom razdoblju prema revizorskim izvješćima objavljenim na stranici Banjalučke burze, pri čemu su njihove vrijednosti ilustrirane prikazom u Tablici 1.

Empirijske vrijednosti indikatora poslovne učinkovitosti omogućuju konstruiranje modela prosječne razvojne tendencije pojedinih pokazatelja u vremenu, kao i to da se rezultati modeliranja koriste u prognostičke svrhe s ciljem projekcije vrijednosti za 2017. godinu, uz pouzdanost $99,9 \%$. Snaga i uporabna vrijednost modeliranih informacija proizlazi iz njihovog empirijskog temelja i nepristranog izvođenja ${ }^{1}$. Modelsko predviđanje pojedinih aspekata poslovnog rezultata realizira se korištenjem linearnog regresijskog modela kojem se prilagođavaju empirijski pokazatelji, a koji predstavlja izdvajanje prosječnog zakonomjernog izraza razvojne tendencije, a može se u općem obliku izraziti obrascem:

$$
\mathrm{Yt}=\mathrm{a}+\mathrm{bx}
$$

U prethodnoj formuli oznake a i b predstavljaju ocjenjene vrijednosti parametara linearnog regresijskog modela (Landika i Mikić, 2015.).

Pregled modeliranih informacija sadržan je u Tablici 2.

Pojedini modelirani pokazatelji ukazuju na korisne upravljačke informacije, od kojih posebnu važnost imaju sljedeće:
Landika, M., Jakupović, S., Šupuković, V.

Modeliranje poslovno ekonomskih strategija kao platforme investicijske politike u uvjetima rizika 
Landika, M., Jakupović, S., Šupuković, V.

Modeliranje poslovno ekonomskih strategija kao platforme investicijske politike u uvjetima rizika

Tablica 2. Modelirane upravljačke informacije u pogledu pokazatelja odgovarajuće razine poslovne učinkovitosti na bazi informacija o njihovoj razini za razdoblje 2009. - 2015. godine, iskazanog u obliku prosječnog zakonomjernog odnosa razine investicijskih ulaganja i ostvarenog neto dobitka

\begin{tabular}{|c|c|c|c|}
\hline $\begin{array}{c}\text { Pokazatelj } \\
\text { razine } \\
\text { aktivnosti }\end{array}$ & $\begin{array}{c}\text { Modelirana } \\
\text { informacija }\end{array}$ & $\begin{array}{c}\text { Jednadžba linearnog } \\
\text { regresijskog modela }\end{array}$ & \begin{tabular}{c} 
Standardna greška modela \\
\hline $\begin{array}{c}\text { Razina poslovnog dobitka u } \\
\text { ovisnosti od razine investiranja }\end{array}$
\end{tabular} \\
\hline
\end{tabular}

Izvor: izrada autora.

Tablica 3. Distribucija vjerojatnosti broja korisnika mobilne telefonije u 2017.godini²

\begin{tabular}{|c|c|c|c|c|}
\hline Broj korisnika $(\mathrm{Nmi})$ & $\mathbf{P}(\mathrm{Nmi})$ & Razredna sredina (Nmi) & 1,345 & $0-3$ \\
\hline Do 1,36 & 0,0354 & 0,0359 & 1,375 & $4-28$ \\
\hline $1,36-1,39$ & 0,2484 & 0,2843 & 1,405 & $29-74$ \\
\hline $1,39-1,42$ & 0,4611 & 0,7454 & 1,435 & $75-96$ \\
\hline $1,42-1,45$ & 0,2246 & 0,9700 & 1,465 & $97-99$ \\
\hline Više od 1,45 & 0,0300 & 1,0000 & - & - \\
\hline Ukupno $(\Sigma)$ & 1,000 & - & & - \\
\hline
\end{tabular}

Izvor: izrada autora.

Tablica 4. Distribucija vjerojatnosti broja korisnika integriranih usluga u 2017. godini

\begin{tabular}{|c|c|c|c|c|}
\hline Broj korisnika (Nii) & P(Nii) & P(Nii)ci & Razredna sredina (Nisi) & Interval slučajnih brojeva \\
\hline Do 102 & 0,0352 & 0,0352 & 100,5 & $0-4$ \\
\hline $102-105$ & 0,1625 & 0,1977 & 103,5 & $5-19$ \\
\hline $105-108$ & 0,3461 & 0,5438 & 106,5 & $20-54$ \\
\hline $108-111$ & 0,2939 & 0,8377 & 109,5 & $55-83$ \\
\hline $111-114$ & 0,1411 & 0,9788 & 112,5 & $84-97$ \\
\hline Više od 114 & 0,0212 & 1 & 115,5 & $98-99$ \\
\hline Ukupno $(\Sigma)$ & 1,000 & & & - \\
\hline
\end{tabular}

Izvor: izrada autora.

- Ostvareni poslovni dobitci imaju tendenciju rasta koju možemo iskazati kao prosječno povećanje od 356.000 BAM po jednom milijunu investiranih sredstava

- Prosječno ostvarena dobit u situaciji bez investicijskih ulaganja iznosi 97.860 .000 BAM

- Prosječno odstupanje od prosječno ostvarene neto dobiti iznosi 6.010 .000 BAM.

Analiza slučaja promatranog poslovnog sustava odnosi se na projektiranje razine investicijskih ulaganja kojim bi se utjecalo na poslovni rezultat, a time i poslovnu učinkovitost. Pretpostavlja se da projektirana razina investiranja promatranog poslovnog sustava ima normalnu raspodjelu i u simulacijskom modelu predstavlja slučajnu varijablu, čija se distribucija vjerojatnosti može prikazati kroz Tablicu 4.

Investicijska aktivnost odnosi se na mogućnost tvrtke da zadovolji potražnju za odgovarajućim pretplatničkim uslugama prema vjerojatnosti njihovog nastanka. Prilikom proračuna poslovne učinkovitosti potrebno je uvažiti mogućnosti zadovoljenja potražnje proizašlih iz investicijskih ulaganja, pri čemu se broj potencijalno raspoloživih usluga oslanja na ulaganje u kapacitete u pogledu pružanja usluga.

Veza između varijabli određena je korištenjem IBM SPSS Statistics 22, a dobiveni su sljedeći rezultati: ${ }^{4}$

2 Vjerojatnost slučajne varijable određena je prema normalnoj distribuciji N(1,404; 0,024)

3 Vjerojatnost slučajne varijable određena je prema normalnoj distribuciji N(107,653; 3,129)

4 Dobivena vrijednost predstavlja očekivanu pretplatu po korisniku u mobilnoj telefoniji 
Slika 1. Regresijski model za izražavanje ovisnosti broja korisnika od visine investiranih sredstava u opremu potrebnu za njihovu realizaciju

\begin{tabular}{|c|c|c|c|}
\hline \multicolumn{4}{|c|}{ Unesene / uklonjene varijable } \\
\hline Model & Unesene varijable & Uklonjene varijable & Metoda \\
\hline 1 & $\begin{array}{l}\text { Broj korisnika integrirane usluge, Broj } \\
\text { korisnika mobilne telefonije }^{b}\end{array}$ & 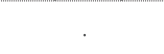 & Unijeti \\
\hline
\end{tabular}

a. Ovisna varijabla: Investirana sredstva

b. Unesene sve tražene varijable.

\begin{tabular}{|c|c|c|c|c|}
\hline \multicolumn{5}{|c|}{ Sažetak modela } \\
\hline Model & $\mathrm{R}$ & R kvadrat & Prilagođeni R kvadrat & $\begin{array}{c}\text { Standardna pogreška } \\
\text { procjene }\end{array}$ \\
\hline 1 & $.616^{\mathrm{a}}$ & .380 & -240 & 38.946824 \\
\hline
\end{tabular}

a. Prediktori: (konstanta),Broj korisnika integrirane usluge, Broj korisnika mobilne telefonije

\begin{tabular}{|c|c|c|c|c|c|c|}
\hline \multicolumn{7}{|c|}{ ANOVA $^{3}$} \\
\hline & lodel & Zbroj kvadrata & Df & Kvadratna sredina & $\mathrm{F}$ & Sig. \\
\hline \multirow{3}{*}{1} & Regresija & 1859.061 & 2 & 929.531 & .613 & $.620 \mathrm{~b}$ \\
\hline & Ostatak & 3033.710 & 2 & 1516.855 & & \\
\hline & Ukupno & 4892.772 & 4 & & & \\
\hline
\end{tabular}

a. Ovisna varijabla: Investirana sredstva

b. Prediktori: (konstanta), Broj korisnika integrirane usluge, Broj korisnika mobilne telefonije

\begin{tabular}{|c|c|c|c|c|c|c|}
\hline \multicolumn{7}{|c|}{ Koeficijentia } \\
\hline \multicolumn{2}{|r|}{ Model } & \multicolumn{2}{|c|}{ Nestandardizirani koeficijenti } & $\begin{array}{l}\text { Standardizirani } \\
\text { koeficijenti }\end{array}$ & \multirow[t]{2}{*}{$\mathrm{t}$} & \multirow[t]{2}{*}{ Sig. } \\
\hline \multirow{4}{*}{1} & & B & St. pogreška & Beta & & \\
\hline & (Konstanta) & -202.616 & 1296.238 & & -156 & .890 \\
\hline & $\begin{array}{l}\text { Broj korisnika mobilne } \\
\text { telefonije }\end{array}$ & 190.921 & 930.941 & .116 & .205 & .856 \\
\hline & $\begin{array}{l}\text { Broj korisnika } \\
\text { integrirane usluge }\end{array}$ & -1.010 & .912 & .625 & -1.107 & .384 \\
\hline
\end{tabular}

a. Ovisna a varijabla: Investirana sredstva

Izvor: izrada autora.

Poslovni portfelj uključuje sljedeće korisničke pakete, uz pretpostavku vjerojatnosti zastupljenosti pojedinih korisničkih paketa u mobilnoj telefoniji i integriranim uslugama, i može se ilustrirati prikazom u Tablicama 5. i 6.

Udio pretplatnika po projektiranim tarifnim modelima podrazumijeva istraživačku pretpostavku temeljenu na iskustvu, platežnoj moći, očekivanim konkurentskim strategijama i tendencijama tehnoloških turbulencija u tangentnim područjima. Važno je naglasiti da se pretplatnički paketi formiraju u trenutku kada potražnja za istima nije poznata, a paketi se isporučuju u trenutku nastanka potražnje.

Neizvjesnost potražnje usluga iz ponude telekomunikacijske tvrtke opravdava primjenu simulacijskog modela, pri čemu se teži optimizaciji poslovanja provjerom učinaka formulirane ponude usluga prije provođenja iste. Komparativna analiza odnosi se na opcije:

- PRAVILO 1. Investiranje prema očekivanoj vrijednosti potražnje pojedinih usluga na tržištu uz izračunavanje propuštene dobiti zbog nemogućno-

Tablica 5. Distribucija korisničkih paketa u mobilnoj telefoniji prema sudjelovanju korisnika

\begin{tabular}{|l|c|c|c|c|c|c|}
\hline Visina pretplate $\left(\mathrm{X}_{\mathrm{i}}\right)$ & 20 & 40 & 60 & 80 & 100 & Ukupno $(\boldsymbol{\Sigma})$ \\
\hline Udjel pretplatnika $\left[\mathbf{P}\left(\mathrm{X}_{\mathrm{i}}\right)\right]$ & 0,25 & 0,25 & 0,20 & 0,20 & 0,10 & 1,000 \\
\hline $\mathbf{P}\left(\mathbf{X}_{\mathbf{i}}\right) \cdot \mathbf{X}_{\mathrm{i}}$ & 5 & 10 & 12 & 16 & 10 & $53,00^{4}$ \\
\hline
\end{tabular}

Izvor: izrada autora. 
Landika, M., Jakupović, S., Šupuković, V.

Modeliranje poslovno ekonomskih strategija kao platforme investicijske politike u uvjetima rizika

Tablica 6. Distribucija korisničkih paketa u integriranim uslugama prema sudjelovanju korisnika

\begin{tabular}{|l|c|c|c|c|c|c|}
\hline Visina pretplate $\left(\mathrm{x}_{\mathrm{i}}\right)$ & 20 & 40 & 60 & 80 & 100 & Ukupno $(\Sigma)$ \\
\hline Udjel pretplatnika $[\mathrm{P}(\mathrm{xi})]$ & 0,21 & 0,25 & 0,21 & 0,1 & 0,1 & 1,000 \\
\hline $\mathbf{P}\left(\mathrm{X}_{\mathrm{fi}}\right) \cdot \mathrm{X}_{\mathrm{ii}}$ & 4,2 & 10 & 12,6 & 13,33 & 16,67 & $56,80^{5}$ \\
\hline
\end{tabular}

Izvor: izrada autora.

Tablica 7. Skupni rezultati matematičke simulacije prihoda telekomunikacijske tvrtke predloženim investicijskim modelima

\begin{tabular}{|c|c|c|c|c|c|c|}
\hline \multirow[b]{2}{*}{$\begin{array}{l}\text { Pravilo } \\
\text { Odlučivanja }\end{array}$} & \multirow[b]{2}{*}{ Stavka } & \multicolumn{2}{|c|}{ Ukupno korisnika (tražnja): } & \multicolumn{2}{|c|}{ Ukupno investirano: } & \multirow[b]{2}{*}{$\begin{array}{c}\text { Ukupan poslovni } \\
\text { dobitak: }\end{array}$} \\
\hline & & $\begin{array}{l}\text { Mobilna } \\
\text { telefonija }\end{array}$ & $\begin{array}{c}\text { Integrirane } \\
\text { usluge }\end{array}$ & $\begin{array}{l}\text { Mobilna } \\
\text { telefonija }\end{array}$ & $\begin{array}{c}\text { Integrirane } \\
\text { usluge }\end{array}$ & \\
\hline \multicolumn{2}{|c|}{ Pravilo 1.} & 16,83 & 1290 & 16,848 & 1291,836 & 113,2721 \\
\hline \multicolumn{2}{|c|}{ Pravilo 2.} & 16,83 & 1290 & 16,829 & 1288,153 & 113,2694 \\
\hline \multicolumn{2}{|c|}{ Razlike po stavkama: } & 0,00 & 0,00 & 0,019 & 3,683 & 0,002739 \\
\hline
\end{tabular}

Izvor: izrada autora.

sti podmirenja iste. Očekivanu vrijednost ostvarene dobiti izračunavamo korištenjem konstruiranog regresijskog modela kod kojega je nezavisna varijabla realizirana vrijednost investicijskih ulaganja

- PRAVILO 2. Investiranje prema potražnji iz prethodnog obračunskog perioda uz iste kalkulativne stavke kao u prethodnom pravilu.

Odgovarajuće provođenje analize zahtjeva metodu generiranja potražnje i definiranje vremenskog intervala za provođenje simulacije, a time i kreiranje platforme za primjenu matematičke simulacije uz korištenje Monte Carlo tehnike.

U Tablicama 4. i 5. formirani su „Intervali slučajnih brojeva“,pri čemu se slučajni broj povezuje s brojem korisnika mobilne telefonije i integriranih usluga u pojedinim mjesecima 2017. godine.

Prethodno predstavljeni informacijski fond predstavlja platformu provođenju simulacije po mjesecima za 2017. godinu. Slučajni brojevi se generiraju funkcijom „Randbetween“, gdje se svakom slučajnom broju pridružuje vrijednost broja pretplatnika u mobilnoj telefoniji i integriranih usluga pretplatničkih modela, gdje se za proračun koriste razredne sredine, a očekivani prihod izračunavamo kao zbroj proizvoda između očekivanog broja korisnika i prihoda po tom osnovu, podijeljen s brojem mjeseci. Navedeno proizlazi iz činjenice da se broj korisnika projektira na godišnjoj razini, a mijenja i prati na mjesečnoj razini.

Rezultati matematičke simulacije ukazuju da se primjeren izbor odnosi na opciju označenu kao PRAVILO 2 u provedenoj analizi jer omogućuje ostvarenje većeg ukupnog godišnjeg poslovnog dobitka u iznosu od 2.739 BAM.

\section{Zaključna razmatranja}

Postizanje optimalne poslovne efikasnosti u nemirnom, nestabilnom i složenom poslovnom okruženju zahtijeva odgovarajuće predviđanje poslovnih rezultata, kako bi se ograničena investicijska sredstva usmjerila na poslovne aktivnosti koje ostvaruju najbolji mogući poslovni rezultat. Poslovni rezultat određuju brojni čimbenici čija je priroda, oblik i mjera utjecaja, često neuočljiva bez složene i suptilne modelske analize. Selekcija teorijskih modela u smislu potentnosti predviđanja poslovnih rezultata izuzetno je značajna u fazi pripreme poslovnih odluka, čime se prevenira ireverzibilnost investiranih sredstava i umanjuju posljedice neželjenih poslovnih ishoda u postupku valorizacije poslovnih alternativa. Adekvatnost modela odlučivanja blisko korespondira s okolnostima kojima se izgrađeni model prilagođava, jer je kompetentnost modeliranih upravljačkih informacija suglasna s mjerom sličnosti između modeliranog sustava i modela kao njegove imaginarne projekcije. Ulaganje i investicijska politika

\section{Dobivena vrijednost predstavlja očekivanu pretplatu po korisniku integralnih usluga}

6 Podrazumijeva vrijednost investicije koju u periodu njezine eksploatacije tržište uspije apsorbirati, a računa se kao manja vrijednost između kapaciteta za pružanje usluga i potražnje za uslugama 
predstavljaju poslovnu platformu poslovne egzistencije posebno u vrijeme intenzivnih tehnoloških promjena, globalizacije tržišta i svijesti dionika 0 potrebama tržišnog pozicioniranja. Mogućnost utjecaja na poslovni ishod zahtijeva sagledavanje korisničkih preferencija, mogućnosti i ukupnih uvjeta privređivanja, kako bi uvrštavanjem u odgovarajući teorijski model osigurali informacijske kapacitete za predviđanje posljedica poslovnih alternativa. Simulacijski modeli omogućavaju da se odabere model investiranja koji se u većoj mjeri prilagođava budućoj potražnji za uslugama telekomunikacijske tvrtke. Izračun profitabilnosti omogućuje da se sagledaju monetarne posljedice poslovnih odluka, što iznosi 2.653 BAM više profita u tijeku jedne godine eksploatacije investicijskog ulaganja u odnosu na drugu opciju, pri čemu modelsko predviđanje obuhvaća značajne čimbenike koji utječu na poslovni ishod. Usporedba poslovnih rezultata ostvarenih tradicionalnim pristupom s rezultatima koji uključuju modelsko predviđanje poslovnih ishoda podrazumijeva diferencijaciju dobrog i najboljeg poslovnog rezultata. Modelsko predviđanje zahtjeva pokretanje intelektualnog kapitala i eventualnu softversku podršku, pri čemu učinci primjene modeliranih upravljačkih informacija premašuju troškove pokretanja njihovih potencijala.

\section{Literatura}

Dean, J. (1951) Managerial Economics. New York: Prentice Hall.

Deloitte (2015) Dostupno na: https://www.blberza.com/Cms2FileCache/files/cms2/docver/55905/files/ TLKM_Mtel_Revidovani\%20konsolidovani\%20finansijski\%20izvjestaji_31.12.2015.pdf.[10.10.2016.].

Deloitte (2016) Dostupno na: http://www.mtel.ba/27.3.2016. from mtel Banja Luka: http://www.mtel.ba/ fin-izvjestaji-korporativne. [10.10.2016.].

Hertz, D. (1990) Risk Analysis in Capital Investment. Chichester: John Wiley\&Sons.

Landika, M., Mikić, Đ. (2015) Metodi statističke analize - primjena u oblasti zdravstvenih, sportskih i inženjerskih nauka. Banja Luka: Panevropski univerzitet "Apeiron".

M.tel Banja Luka (2015) Dostupno na: http://www.mtel.ba/images/content/Fin_izvjestaji/2015/Godisnji_2015.pdf: http://www.mtel.ba/ [18.8.2016.].

Mikić,Đ.(2006) Teorija i strategija odlučivanja - kriterijumski izbor upravljačkih akcija. Banja Luka: Panevropski univerzitet "Apeiron". 
